\title{
VARIATION OF MORPHOLOGICAL NEEDLE CHARACTERS OF SCOTS PINE (PINUS SYLVESTRIS L.) POPULATIONS IN DIFFERENT HABITATS
}

\author{
LECH URBANIAK ${ }^{1}$, LESZEK KARLIŃSKI ${ }^{1,2}$, REMIGIUSZ POPIELARZ ${ }^{3}$ \\ ${ }^{1}$ Department of Genetics, Adam Mickiewicz University \\ Miedzychodzka 5, 60-371 Poznan, Poland \\ e-mail: carexu@amu.edu.pl \\ 2 Polish Academy of Sciences, Institute of Dendrology \\ Parkowa 5, 62-035 Kornik, Poland \\ e-mail: 1.karlinski@interia.pl \\ 3 Tuchola Protected Landscape Area \\ Podgorna 1, 89-500 Tuchola, Poland
}

(Received: November 23, 2000. Accepted: November 20, 2001)

\begin{abstract}
We investigated the phenotypic variation of five morphological needle characters of Scots pine (Pinus sylvestris L.) in three populations. Two of the populations occurred in bogs and the third one formed a degraded fresh pine forest showing some features of a dry pine forest. The greatest variation was found in characters a (needle length), $b$ and $d$, denoting the number of stomatal rows respectively on the convex and flat sides of the needle. Conversely, characters $\mathrm{c}$ and e (average number of stomata per $2 \mathrm{~mm}$ of needle length on the convex and the flat side of the needle) were stable, with little interindividual variation. The two bog populations and the dryland population exhibited different sets of character correlations. The interpopulation differentiational detected on the basis of morphological character expression was markedly influenced by both the different edaphic conditions, and the distinct genetic structure of the studied populations.
\end{abstract}

KEY WORDS: Pinus sylvestris L., morphological variation, needles, different habitats.

\section{INTRODUCTION}

The considerable genetic variability and phenotypic plasticity of Scots pine, enabling this species to adapt often to extreme environmental conditions, allowed it to colonize an enormous territory, from mountain areas of the Iberian Peninsula all the way to the isolated localities in East Siberia, spanning ca. 14000 kilometer range. The latitudinal range of Scots pine is also impressive because it extends over the entire Scandinavian Peninsula and northern territories of the European part of Russia, reaching to the southernmost extreme the Sierra Nevada mountains in Spain and the Turkish Anatholia area in Asia (Boratyński 1993).

Scots pine (Pinus sylvestris L.) is a species of a broad ecological scale and low thermal requirements. Populations of this species are found in habitats with high ground water level, such as bogs and swamp forests. The other extreme of its edaphic adaptive abilities are the populations forming the dry coniferous forest (Obmiński 1970; Przybylski 1993; Oleksyn 1993). This contrasts with the adaptation to mountain conditions (Zajączkowki 1949). In Tuchola Forest, where Scots pine has been the dominant species for at least 10000 years, it occupies diverse habitats (Tobolski 1988; Boiński 1992).

At least some of the morphological and anatomical needle characters can be subject to considerable modification in response to varying environmental conditions (Pravdin 1964; Vidâkin 1981; Urbaniak 1998). Identification of such characters may be crucial for describing the reaction norm of studied populations to environmental stress.

It is important to realize that variation and genetic differentiation may represent alternative modes of adaptation to diverse environmental conditions.

The objectives of this work are focused on identifying constant characters with little variation. To determine variation and the reaction norm for each population, we targeted characters subject to environmental modifications. Intercharacter correlations were determined in order to uncover genetically based differences between populations. Further, we evaluated the importance of the selected morphological characters of needles for overall pattern of diversification between populations from the two edaphically extreme (i.e. moist and dry) habitat types of the Tuchola Forest.

\section{MATERIALS AND METHODS}

This investigation was conducted in Tuchola Protected Landscape Area where pine forests are the dominant vegetation type. Scots pine occupies both nutrient-poor sand fields and sites with peat-based soils (Boiński 1992; Banaszak and Tobolski 1998). 


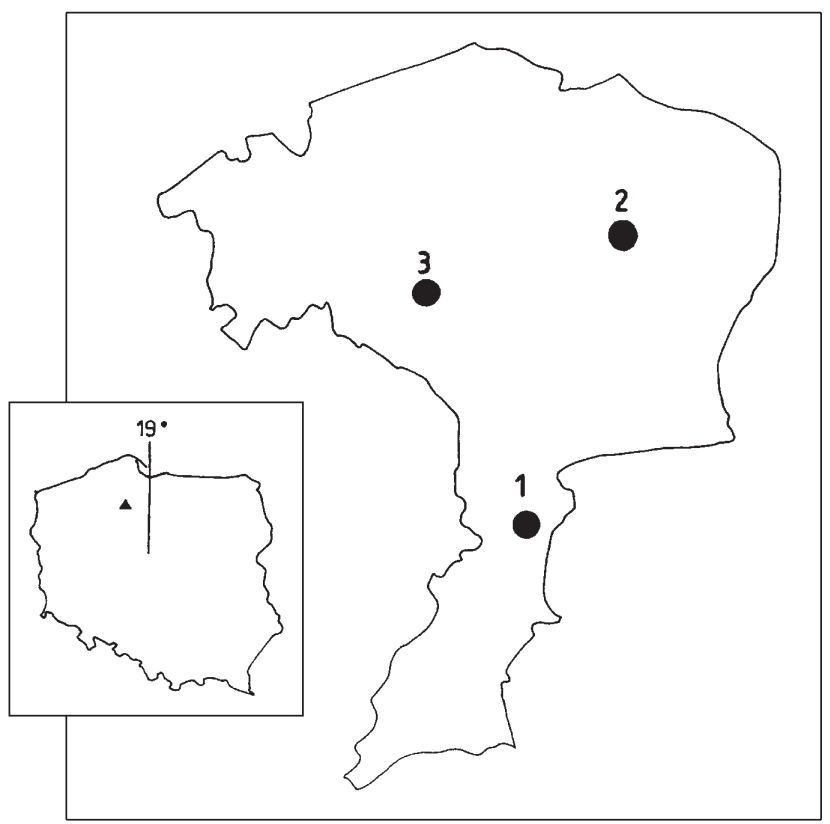

Fig. 1. Geographical position of sampling sites. The left down map gives an overview of Poland and the location of Tuchola Protected Landscape Area (triangle). The right map shows position of the individual sampling sites on the area of the Tuchola Pine Forests - populations of Scots pine (Pinus sylvestris L.): 1 (Jelenia Wyspa), 2 (Chrobotkowy Bór) and 3 (Jeziorka Kozie).

Scots pine needles used in this research were collected in the first week of March 1999 from the following three populations located in the Tuchola Protected Landscape Area (part of the Tuchola Forest): 1 (Jelenia Wyspa) - about 20year old natural stand growing in a raised bog, with an abundant growth of Ledum palustre L. and an occasional occurrence of Alnus glutinosa L. and Betula pubescens Ehrh.; 2 (Chrobotkowy Bór) - degraded fresh pine forest revealing some features of a dry pine forest, aged about 65 years, with localized patches of Betula verrucosa Ehrh. (also aged 65 years) and Junipereus communis L. in the undergrowth. Cladina stellaris (Opiz) Brodo is found on the floor of about $1 / 5$ of the area, pedzolic soil on eolic sands; 3 (Jeziorka Kozie) - Scots pine aged 15-25 years growing in peaty soil typical of raised bogs. Part of the needles were collected from trees surrounding a distrophic lake and the remaining ones from trees growing on floating moss mats near the lake's shore.

The location of the Tuchola Forest within the Polish territory is presented in Fig. 1. Needles were harvested from 30 individuals from each population. The long shoots were cut from each individual, and ten 2-year old needles, each from a different shoot, were then collected and used in measurements of the following morphological characters, describing an individual tree: a (needle length) $(\mathrm{mm})$, $\mathrm{b}$ (number of stomatal rows on the convex side of the needle), c (average number of stomata per $2 \mathrm{~mm}$ of needle length on the convex side), $d$ (number of stomatal rows on the flat side of the needle), e (average number of stomata per $2 \mathrm{~mm}$ of needle length on the flat side). In each of the trees, constituing a population sample, morphological characters of 10 needles were examined. The following statistical analyses were conducted on values averaged for each individual: basic characteristics of the characters (mean, median, minimum and maximum values, range, standard deviations, variation coefficients, skewness and curtosis); agglomerative grouping using the method of the nearest neighbour based on Euklidean distances (dendrogram); correlation coefficients between the character values; Tukey's test; Snedecor's $F$ statistics; Shapiro-Wilk's normality test. All the statistical calculations were done using Statistica computer program.

\section{RESULTS}

\section{Snedekor's F statistics (from analysis of variance)}

Based on the $F$ values showing significant differences among means from the three populations; the highest degree of variation was found for character a (needle length) $(F=149.7, P<0.001)$. Characters b (number of stomatal rows on the convex side of the needle) and $d$ (number of

TABLE I. Basic statistical characteristics of five analyzed morphological needles characters - a (needle lenght), b (number of stomatal rows on the convex side of the needle), c (average number of stomata per $2 \mathrm{~mm}$ of needle lenght on the convex side), $\mathrm{d}$ (number of stomatal rows on the flat side of the needle), e (average number of stomata per $2 \mathrm{~mm}$ of the needle lenght on the flat side).

\begin{tabular}{|c|c|c|c|c|c|c|c|c|c|c|}
\hline Populations & Traits & Mean & Median & Minimum & Maximum & Range & $\begin{array}{c}\text { Standard } \\
\text { deviations }\end{array}$ & $\begin{array}{c}\text { Variations } \\
\text { oefficients \% }\end{array}$ & Skewness & Curtosis \\
\hline \multirow[t]{5}{*}{ 1. Jelenia Wyspa } & $\mathrm{a}$ & 32.8 & 32.4 & 19.8 & 46.8 & 27.0 & 6.6 & 20.2 & 0.25 & -0.15 \\
\hline & $\mathrm{b}$ & 9.4 & 9.4 & 7.4 & 12.3 & 4.9 & 1.2 & 13.1 & 0.64 & 0.01 \\
\hline & $\mathrm{c}$ & 25.4 & 25.4 & 22.7 & 28.0 & 5.3 & 1.3 & 5.1 & -0.02 & -0.31 \\
\hline & d & 8.6 & 8.6 & 6.3 & 11.1 & 4.8 & 1.2 & 13.4 & -0.09 & -0.35 \\
\hline & e & 26.2 & 26.2 & 23.6 & 29.2 & 5.6 & 1.4 & 5.3 & 0.12 & -0.32 \\
\hline \multirow[t]{5}{*}{ 2. Chrobotkowy Bór } & $\mathrm{a}$ & 58.4 & 57.1 & 39.2 & 77.3 & 38.1 & 9.0 & 15.4 & 0.06 & 0.05 \\
\hline & $\mathrm{b}$ & 10.3 & 10.0 & 8.6 & 14.2 & 5.6 & 1.3 & 12.5 & 1.23 & 1.47 \\
\hline & $\mathrm{c}$ & 24.4 & 24.6 & 21.1 & 26.9 & 5.8 & 1.2 & 5.0 & -0.40 & 0.79 \\
\hline & $\mathrm{d}$ & 9.7 & 9.4 & 8.7 & 13.2 & 4.5 & 1.1 & 10.8 & 1.46 & 2.51 \\
\hline & e & 24.5 & 24.6 & 21.9 & 26.5 & 4.6 & 1.1 & 4.4 & -0.20 & -0.11 \\
\hline \multirow[t]{5}{*}{ 3. Jeziorka Kozie } & a & 30.3 & 28.9 & 23.6 & 41.0 & 17.4 & 4.4 & 14.5 & 0.50 & -0.25 \\
\hline & $\mathrm{b}$ & 8.0 & 7.7 & 6.2 & 10.3 & 4.1 & 1.0 & 12.9 & 0.43 & -0.29 \\
\hline & c & 24.6 & 25.1 & 21.8 & 27.2 & 5.4 & 1.5 & 6.1 & -0.10 & -1.13 \\
\hline & $\mathrm{d}$ & 7.7 & 7.6 & 5.2 & 10.7 & 5.5 & 1.3 & 17.5 & 0.41 & -0.20 \\
\hline & $\mathrm{e}$ & 25.3 & 25.0 & 22.6 & 28.7 & 6.1 & 1.7 & 6.6 & 0.22 & -0.60 \\
\hline
\end{tabular}


TABLES 2.1-2.3. Correlation matrix beetwen five characters: a (needle lenght), b (number of stomatal rows on the convex side of the needle), c (average number of stomata per $2 \mathrm{~mm}$ of needle lenght on the convex side), d (number of stomatal rows on the flat side of the needle), e (average number of stomata per $2 \mathrm{~mm}$ of needle lenght on the flat side) in three Scots pine populations - 1 (Jelenia Wyspa), 2 (Chrobotkowy Bór), 3 (Jeziorka Kozie), (x - significant value at the level of 0,05$)$.

TABLE 2.1. (Jelenia Wyspa).

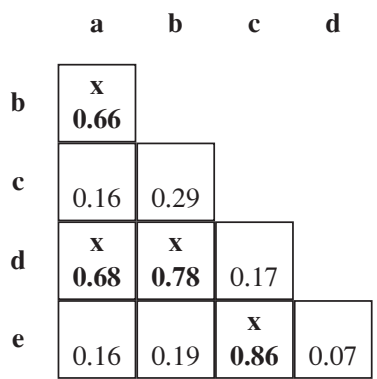

TABLE 2.2. (Chrobotkowy Bór).

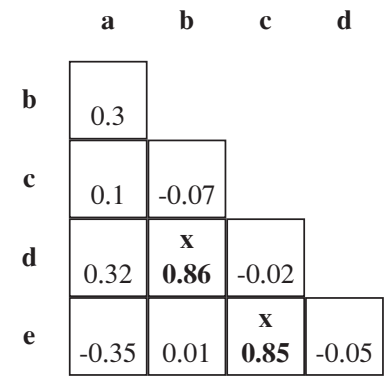

TABLE 2.3. (Jeziorka Kozie).

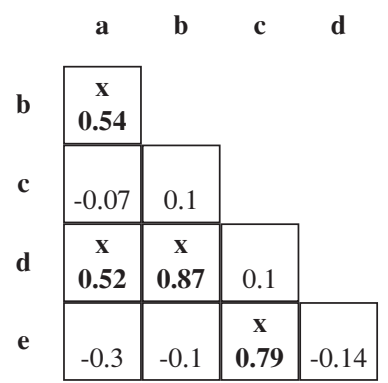

stomatal rows on the flat side of the needle) indicated also that the populations were differentiated, although to a much lower extent $(F=29.5$ and 22.7 , respectively, $P<0.01)$.

The lowest influence on interpopulational differentiation was detected for characters c (average number of stomata per $2 \mathrm{~mm}$ of needle length on the convex side) $(F=4.4$, $P<0.05$ ) and e (average number of stomata per $2 \mathrm{~mm}$ of needle length on the flat side) $(F=11.7, P<0.01)$.

\section{Variation coefficients}

Table 1 summarizes the descriptive statistics for each population with respect to the five analyzed characters. Characters c (average number of stomata per $2 \mathrm{~mm}$ of needle length on the convex side) and e (average number of stomata per $2 \mathrm{~mm}$ of needle length on the flat side) were the most constant, as indicated by coefficients of variation, with the values between 4.4-6.6\%.

The remaining characters: a (needle length), $b$ (number of stomatal rows on the convex side of the needle) and d (number of stomatal rows on the flat side of the needle) displayed a considerable variation -10.8 to $20.2 \%$ (Table 1 ).

\section{Correlations of character}

Both bog populations, i.e. 1 (Jelenia Wyspa) and 3 (Jeziorka Kozie) were characterized by correlations of a (needle length) with $b$ (number of stomatal rows on the convex side of the needle) and $d$ (number of stomatal rows on the flat side of the needle) (Tables 2.1., 2.3.). No such correlations were apparent in population 2 (Chrobotkowy Bór) (Table 2.2.).

In addition, all three populations shared the correlations between characters $b$ (number of stomatal rows on the convex side of the needle) and d (number of stomatal rows on the flat side of the needle), and between characters c (average number of stomata per $2 \mathrm{~mm}$ of needle length on the convex side) and e (average number of stomata per $2 \mathrm{~mm}$ of needle length on the flat side) (Table 2.1., 2.2., 2.3.).

\section{Shapiro-Wilk's normality test}

Based on the comparison of Shapiro-Wilk's normality tests (Figs 2.1.1.-2.3.5.), as well as the descriptive parameters of character distribution (skewness and curtosis) (Table 1), we detected similarity between populations 1 (Jelenia Wyspa) and 3 (Jeziorka Kozie). Both of these populations showed negative curtosis values, except for character b (number of stomatal rows on the convex side of the needle) in population 1 (Jelenia Wyspa). The character values are therefore, less clustered around the mean than expected for a typical normal distribution. This pattern was particularly pronounced in population 3 (Jeziorka Kozie) for characters c (average number of stomata per $2 \mathrm{~mm}$ of needle length on the convex side) and e (average number of stomata per $2 \mathrm{~mm}$ of needle length on the flat side) (Figs 2.3.3. and 2.3.5.).

Population 2 (Chrobotkowy Bór) was clearly distinct because of its positive curtosis values, except for character e (average number of stomata per $2 \mathrm{~mm}$ of needle length on the flat side), where curtosis was slightly negative (Table 1, Fig. 2.2.5.). Character values in this population are more tightly clustered around the mean, and their distribution plots are slimmer (Table 1, Figs 2.2.1.-2.2.4.).

The Shapiro-Wilk's test confirmed the normality of the distribution for most of the investigated characters (Figs 2.1.1.-2.1.5., 2.2.1., 2.2.3., 2.2.5., 2.3.1.-2.3.5.). A remarkable exception was found in population 2 (Chrobotkowy Bór) for characters $b$ (number of stomatal rows on the convex side of the needle) and d (number of stomatal rows on the flat side of the needle), the distribution of which was not normal. This was reflected in the right-skewed asymmetry of their distribution plots and in the skewness values (Figs 2.2.2. and 2.2.4., Table 1).

\section{Grouping analysis}

The grouping analysis was carried out in two steps. First, all five needle characters were included (Fig. 3.1.). On the other hand, the second dendrogram was constructed while omitting character 1 (needle length) (Fig. 3.2.). The purpose of this procedure was to evaluate the contribution of a character considered to be responsive to environmental influences to the overall pattern of interpopulational differentiation.

The branch length of population 2 (Chrobotkowy Bór) was considerable in the case of all characters (Fig. 3.1.). After remowing character a (needle length) and conducting grouping analysis based on four characters, b and d, c and $\mathrm{e}$, which described both the number of stomatal rows and the number of stomata per $2 \mathrm{~mm}$ of needle length on the convex and flat side of the needle, the branch length decreased by as much as a factor of 10 (Fig. 3.2.).

On the one hand, this comparison shows how much character a (needle length) influences the branch length, and 
Fig. 2.1.1.-2.1.5. Shapiro-Wilk's normality test for five characters (a-e) analyzed in population 1 (Jelenia Wyspa).

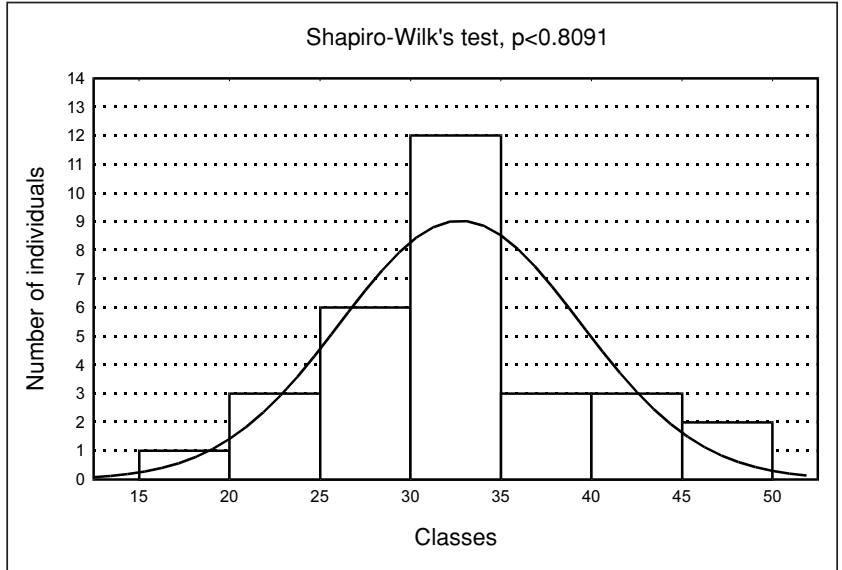

Fig. 2.1.1. a (needle lenght).

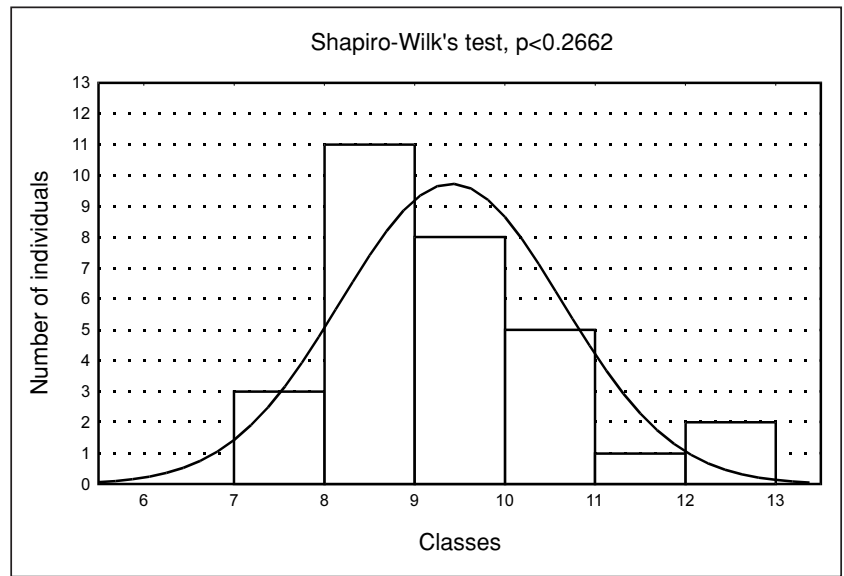

Fig. 2.1.2. b (number of stomatal rows on the convex side of the needle).

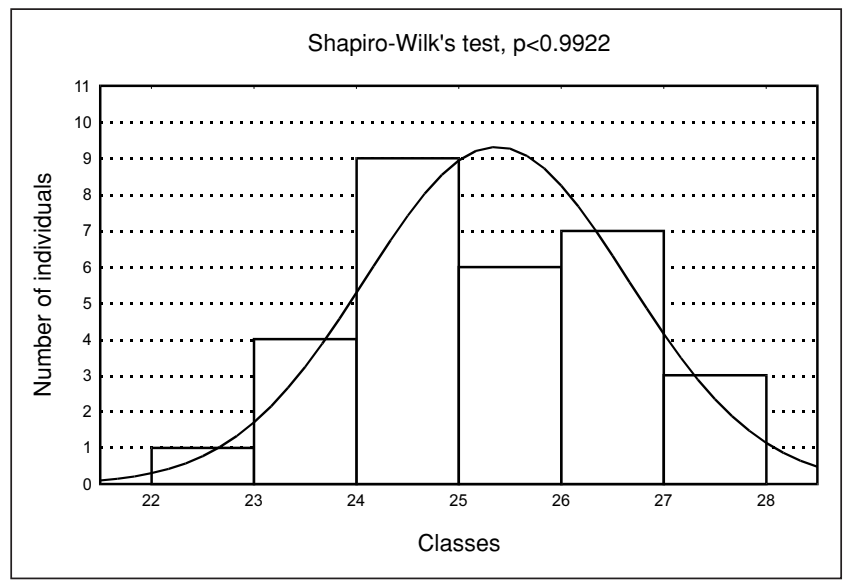

Fig. 2.1.3. c (average number of stomata per $2 \mathrm{~mm}$ of needle lenght on the convex side).

hence the overall differentiation pattern among Scots pine populations. On the other hand, it demonstrates the extent to which this character is subject to environmentally induced modifications.

\section{Tukey's test}

The significance of differences among population averages for the five studied characters was tested using Tukey's test (Tables 3.1.-3.5.). The average value of character a (needle length) indicated the separateness of popu-

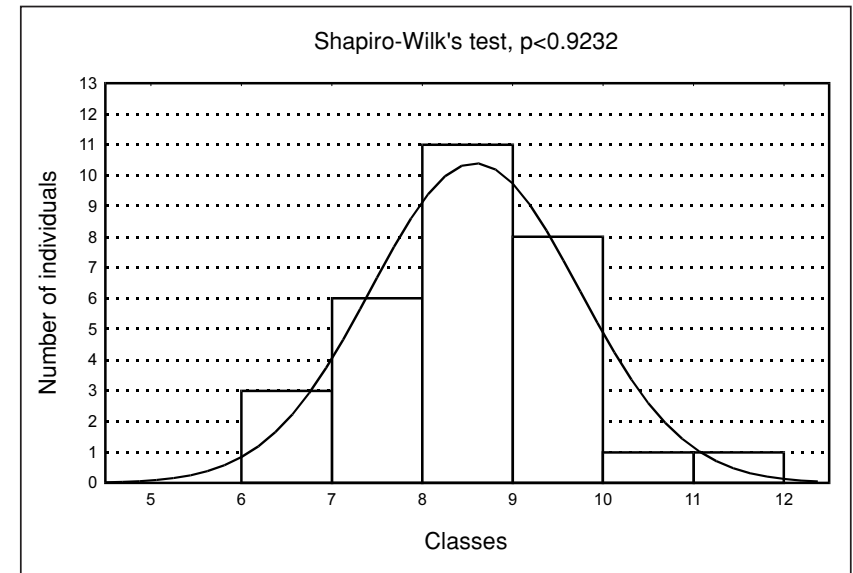

Fig. 2.1.4. $\mathrm{d}$ (number of stomata rows on the flat side of the needle).

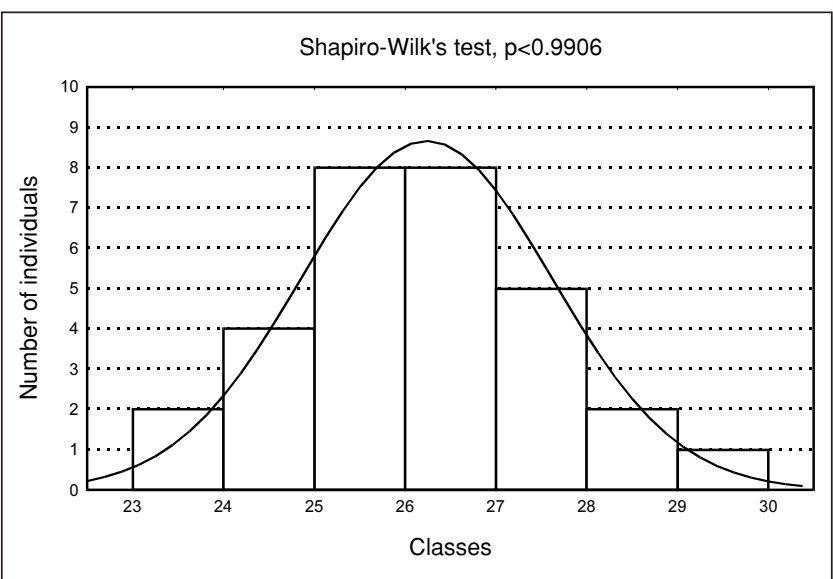

Fig. 2.1.5. e (average number of stomata per $2 \mathrm{~mm}$ of needle lenght on the flat side).

lations 3 (Jeziorka Kozie) and 1 (Jelenia Wyspa) from population 2 (Chrobotkowy Bór) (Table 3.1).

All populations differed significantly with regard to average values of characters $b$ (number of stomatal rows on the convex side of the needle) and $d$ (number of stomatal rows on the flat side of the needle) (Tables 3.2. and 3.4.).

Conversely, characters c (average number of stomata per $2 \mathrm{~mm}$ of needle length on the convex side) and e (average number of stomata per $2 \mathrm{~mm}$ of needle length on the flat side) point to the separateness of population 1 (Jelenia Wyspa) (Tables 3.3. and 3.5.), except that, with respect to character c, population 1 (Jelenia Wyspa) differs only from population 2 (Chrobotkowy Bór), but not from population 3 (Jeziorka Kozie) (Table 3.3.).

\section{DISCUSSION}

Some of the morphological characters of Scots pine needles, such as numbers of stomata on their convex and flat sides, are under strict genetic control and display little variation because they are only to a small extent modified by environmental influences (Mergen 1958; Żelawski and Gowin 1966; Urbaniak 1998). Furthermore, Żelawski and Gowin (1967) found no correlation between these characters and needle length, which was also confirmed (Tables 2.1.-2.3.). Stomatal densities are therefore well suited as indices of genetic differentiation. This is also reflected in 
Fig. 2.2.1.-2.2.5. Shapiro-Wilk's normality test for five characters (a-e) analyzed in population 2 (Chrobotkowy Bór).

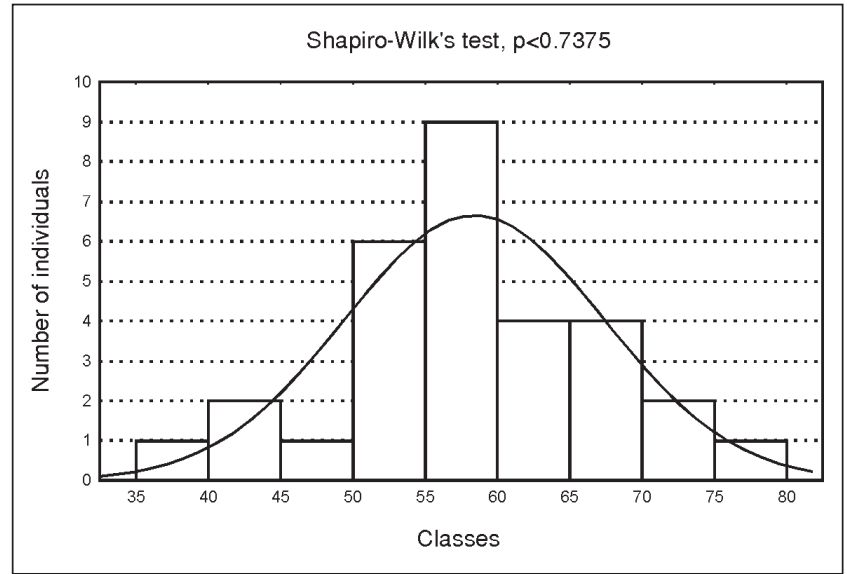

Fig. 2.2.1. a (needle lenght).

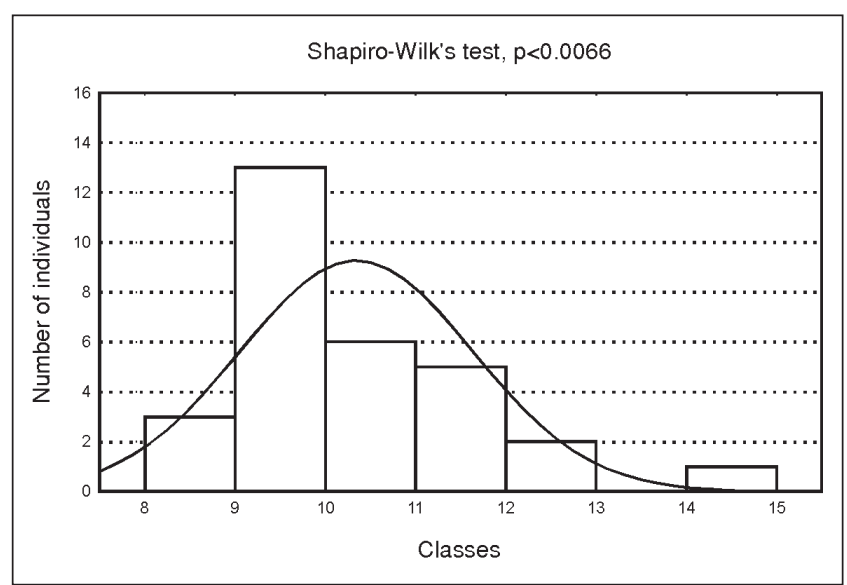

Fig. 2.2.2. b (number of stomatal rows on the convex side of the needle).

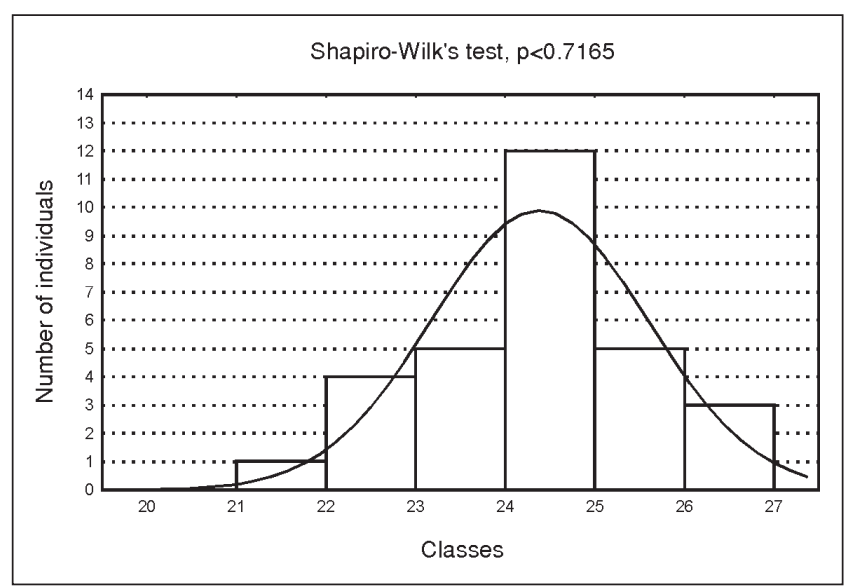

Fig. 2.2.3. c (average number of stomata per $2 \mathrm{~mm}$ of needle lenght on the convex side).

our results where coefficients of variation for these characters are the lowest (Table 1). At the same time, the contribution of these characters to interpopulational differentiation is also the least, as demonstrated by the lowest, even if statistically significant, Snedecor's $F$ values. Investigations of Scots pine from Wielkopolski National Park indicated also that the stomatal number is a constant character with little intraindividual variation (Urbaniak et al. 2000).

On the other hand, character a (needle length) possessed an entirely different set of characteristics. Its variation was

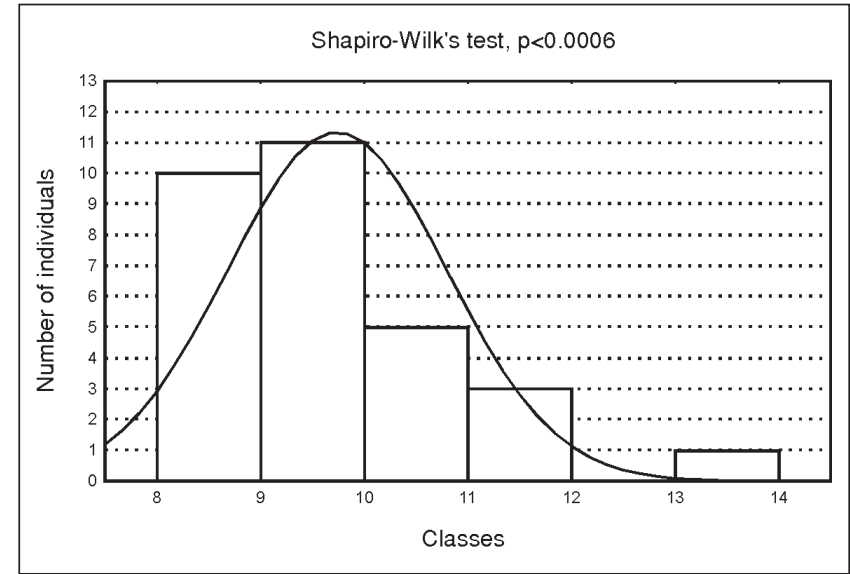

Fig. 2.2.4. $\mathrm{d}$ (number of stomata rows on the flat side of the needle).

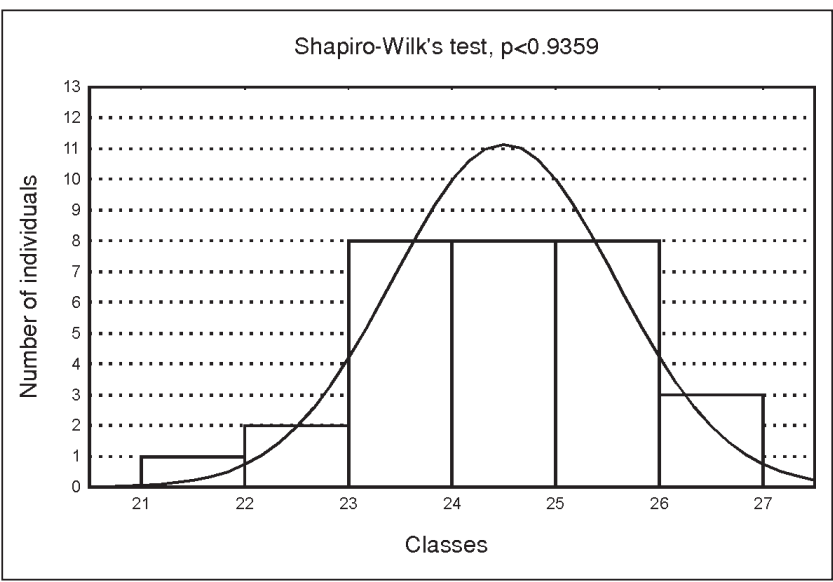

Fig. 2.2.5. e (average number of stomata per $2 \mathrm{~mm}$ of needle lenght on the flat side).

the largest and Snedecor's $F$ statistics achieved the highest values among the studied characters, which implies a considerable influence of this character on interpopulational differentiation. The large variation of this character is well known, and it is a result of its responsiveness to both climatic and edaphic environmental factors (Sokołowski 1931; Pravdin 1964; Żelawski and Niwiński 1966; Żelawski and Gowin 1966; Mamaev 1972). Conseqently, this character may be used in evaluating, differentiation of pine populations in response to environmental heterogenity. Its use for measuring, differentiation of populations is particularly recommended when the needles originated from a common garden experiment in which several populations are compared. For such studies, needles from all populations should be collected in the same year.

The finding that the three studied populations show the same character correlations to us as no surprise. An analogous observation was made in 30 out of 32 Eurasian provenances of Scots pine (Urbaniak 1998).

On the other hand, distinct character correlations were observed for the two bog populations, i.e.: populations -1 (Jelenia Wyspa) and 3 (Jeziorka Kozie), and for the dry pine forest -2 (Chrobotkowy Bór).

Characters $b$ and $d$, which characterized the number of stomatal rows on the convex and the flat sides of the needles, exhibited a pronounced variation (Table 1), which is typical for Scots pine (Urbaniak 1998). 
Fig. 2.3.1.-2.3.5. Shapiro-Wilk's normality test for five characters (a-e) analyzed in population 2 (Jeziorka Kozie).

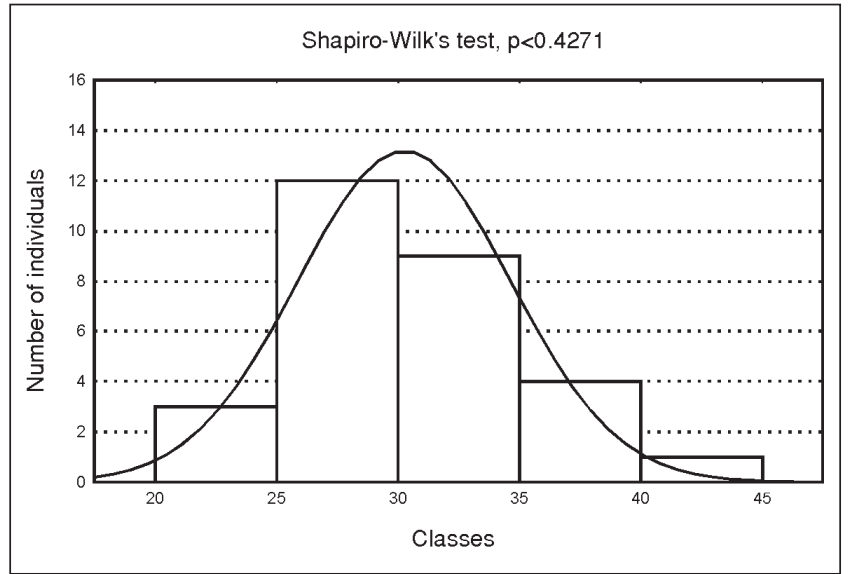

Fig. 2.3.1. a (needle lenght).

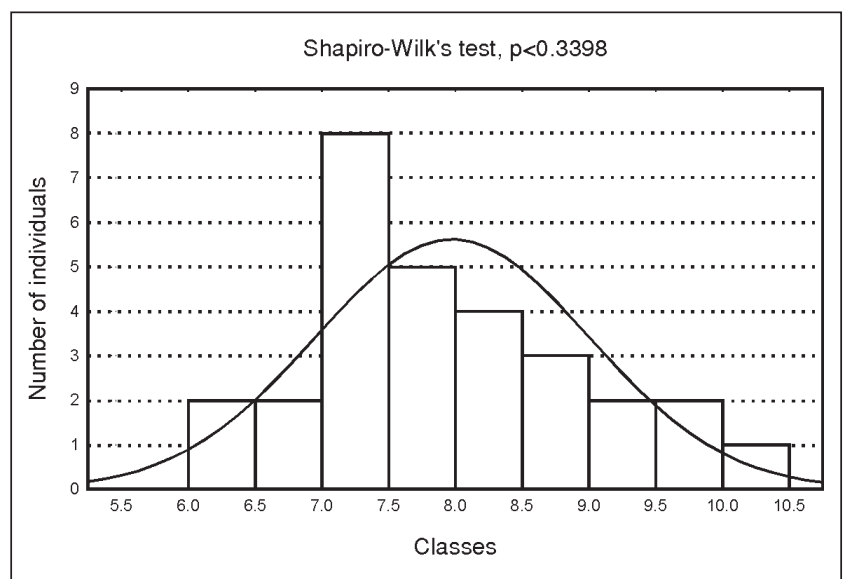

Fig. 2.3.2. b (number of stomatal rows on the convex side of the needle).

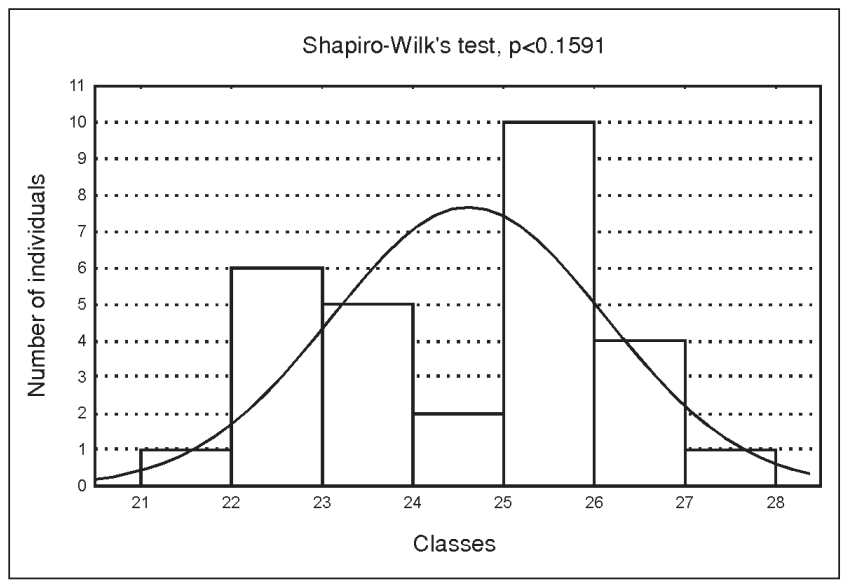

Fig. 2.3.3. c (average number of stomata per $2 \mathrm{~mm}$ of needle lenght on the convex side).

Reported here for the first time is the remarkable lack of normality of the distribution patterns of these characters in population 2 (Chrobotkowy Bór). It is reflected in the right-skewed asymmetry of distribution plots and in measures of skeweness (Figs 2.2.2. and 2.2.4., Table 1). In the case of these two characters, the majority of individuals displayed low numbers of stomatal rows. This tendency points to a strong selection pressure acting on these two characters in population 2 (Chrobotkowy Bór). This could result from the particular edaphic conditions, responsible for creating this type of variation.

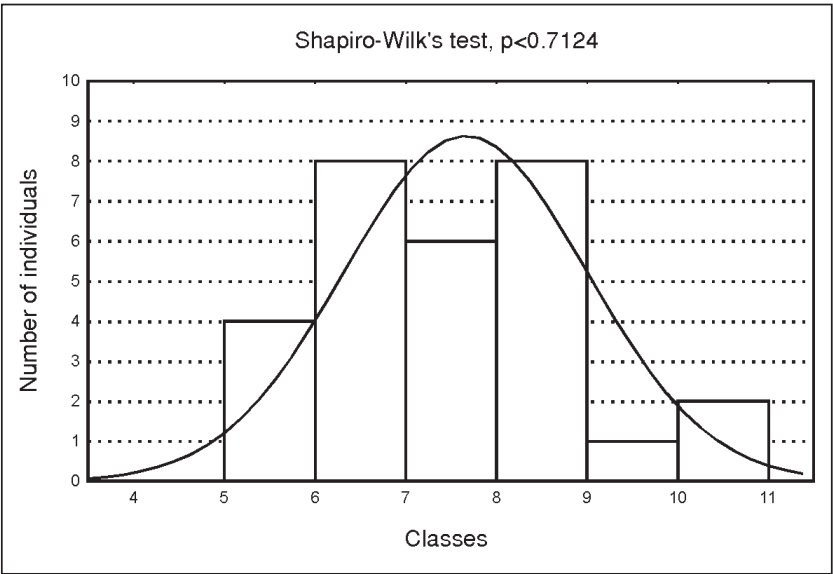

Fig. 2.3.4. $\mathrm{d}$ (number of stomata rows on the flat side of the needle).

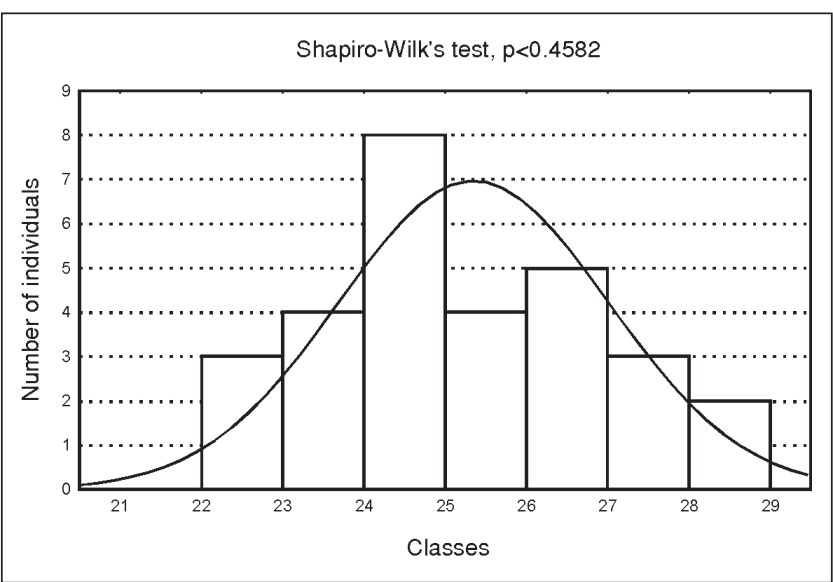

Fig. 2.3.5. e (average number of stomata per $2 \mathrm{~mm}$ of needle lenght on the flat side).

The knowledge of inter- and intrapopulational differentiation of such distinctly adapted populations is crucial in preserving the species' gene pool. In addition, it allows to understand and interpret the evolutionary forces behind this differentiation. The dendrograms, in which the differentiation is presented graphically, indicate the separateness of Scots pine populations 1 (Jelenia Wyspa) and 3 (Jeziorka Kozie), both growing in bogs, from the dryland population 2 (Chrobotkowy Bór) (Figs 3.1., 3.2.). Dissimilarity of the edaphic factors appears to influence the level of differentiation between the populations. This becomes apparent when character a (needle length) is omitted from grouping analysis. While the general pattern of differentiation did not change, the branch length of population 2 (Chrobotkowy Bór) dropped over 10-fold (Fig. 3.2.).

Characters showing little variation, such as c (average number of stomata per $2 \mathrm{~mm}$ of needle length) and e (average number of stomata per $2 \mathrm{~mm}$ of needle length on the flat side) are particularly useful for measuring interpopulational differentiation. In Tukey's test, they point to the distinctness of population 1 (Jelenia Wyspa) (Tables 3.3. and 3.5.). With regard to character $\mathrm{c}$, the latter population is not different from population 3 (Jeziorka Kozie) which occupies a similar environment (Table 3.3.). In contrast, as far as character e is concerned, population 1 (Jelenia Wyspa) is clearly distinct (Table 3.5.). 
TABLES 3.1-3.5. Results of Tukey's test for the five studied characters (arabic numbers denote Scots pine populations - 1 (Jelenia Wyspa), 2 (Chrobotkowy Bór), 3 (Jeziorka Kozie), x - significance differences on the level 0.05).

TABLE 3.1. a (needle length).
TABLE 3.2. b

(number of stomatal rows on the convex side of the needle).
TABLE 3.3. c (average number of stomata per $2 \mathrm{~mm}$ of needle lenght on the convex side).
TABLE 3.4. d

(number of stomatal rows on the flat side of the needle).
TABLE 3.5. e (average number of stomata per $2 \mathrm{~mm}$ of needle lenght on the flat side)

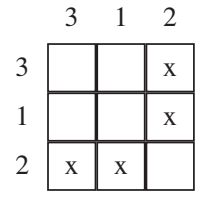

\begin{tabular}{c|c|c|c|}
\multicolumn{1}{c}{3} & 1 & \multicolumn{1}{c}{2} \\
\cline { 2 - 4 } 3 & & $x$ & $x$ \\
\cline { 2 - 4 } 1 & $x$ & & $x$ \\
\cline { 2 - 4 } 2 & $x$ & $x$ & \\
\hline
\end{tabular}

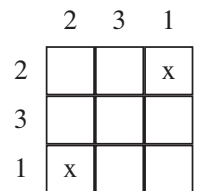

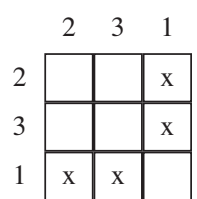

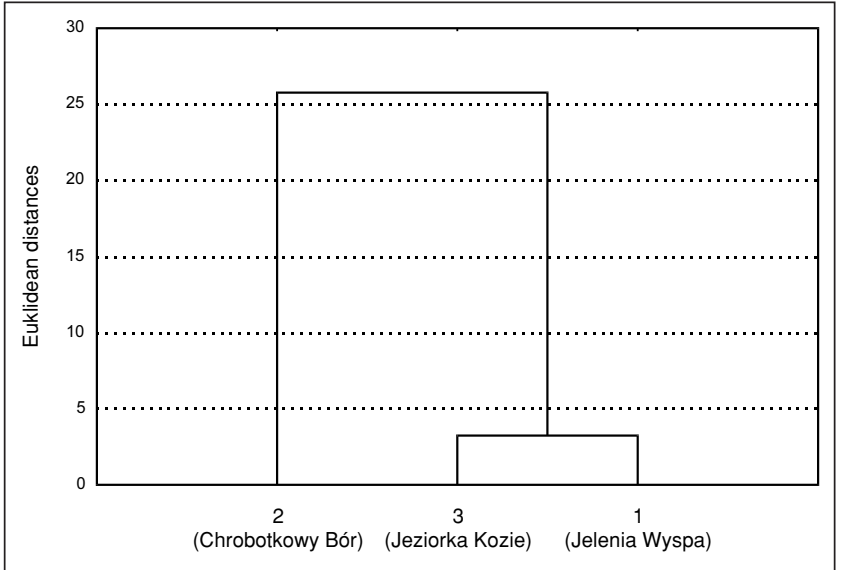

Fig. 3.1. Dendrogram of population groups based on five morphological characters (a-e) showing relationship among populations of Scots pine originated from different habitats.

Characters $b$ (number of stomatal rows on the convex side of the needle) and d (number of stomatal rows on the flat side of the needle) allow to differentiate between the studied populations (Tables 3.2., 3.4.). Moreover, these characters show a considerable variation within populations and are responsible for their highly significant differentiation, as indicated by the Snedecor's $F$ values. It is likely that they are subject to a modifying influence of the environment, which affects the length and the width of the needles and, consequently, the number of stomatal rows. Character - correlation analysis indicates a statistically significant association between needle length and the number of stomatal rows on the convex and flat side of the needle (Tabs. 2.1. and 2.3.). This correlation is positive, thus, the longer the needle, the greater the number of stomatal rows. Therefpre, these characters are less valubale as a source of information about the interpopulational differentiation of Scots pine. On the other hand, they do reflect the scope of plastic response of populations to diverse environments.

\section{LITERATURE CITED}

BANASZAK J., TOBOLSKI K. 1998. Park Narodowy Bory Tucholskie. Wydawnictwo Uczelniane Wyższej Szkoły Pedagogicznej w Bydgoszczy. (in Polish)

BOIŃSKI M. 1992. Osobliwości szaty roślinnej Borów Tucholskich (przewodnik). (in Polish)

BORATYŃSKI A. 1993. Systematyka i geograficzne rozmieszczenie. In: Biologia sosny zwyczajnej, S. Białobok, A. Bora-

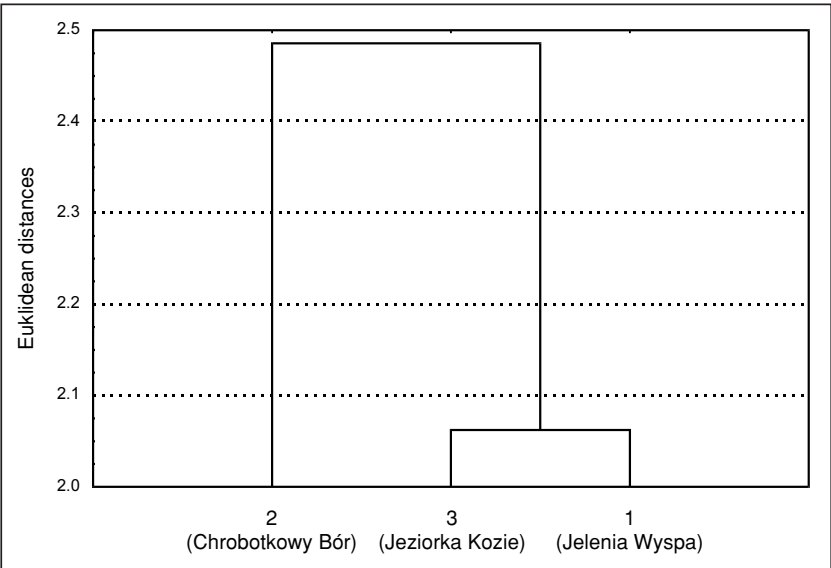

Fig. 3.2. Dendrogram of population groups based on four morphological characters (without a (needle lenght) showing relationship among populations of Scots pine originated from different habitats.

tyński, W. Bugała (eds.), 45-66. Wyd. Sorus, Poznań-Kórnik. (in Polish)

MAMAEV S.A. 1972. Formy vnutrividovoj izmencivosti drevesnych rastenij. Nauka, Moskva. (in Russian)

MERGEN F. 1958. Genetic variation in needle characteristics of Slash pine and in some of its hybrids. Silvae Genetica 1: 1-9.

OBMIŃSKI Z. 1970. Zarys ekologii. Ecology in outline. In: Sosna zwyczajna, Nasze drzewa leśne. S. Białobok (ed.). PWN, Warszawa-Poznań, Vol. 1: 152-231. (in Polish, with English summary)

OLEKSYN J. 1993. Zróżnicowanie wrażliwości na działanie szkodliwych czynników abiotycznych. In: Biologia sosny zwyczajnej, S. Białobok, A. Boratyński, W. Bugała (eds.), Sorus, Poznań-Kórnik, pp. 395-404. (in Polish)

PRAVDIN L.F. 1964. Sosna obyknovennaâ izmencivost' vnutrividovaâ sistematika i selekciâ (Scots pine, Variability, Systematics and Improvement). Nauka, Moskva. (in Russian)

PRZYBYLSKI T. 1993. Autekologia i synekologia. In: Biologia sosny zwyczajnej, S. Białobok, A. Boratyński, W. Bugała (eds.), Sorus, Poznań-Kórnik, pp. 255-276. (in Polish)

SOKOŁOWSKI S. 1931. Prace biometryczne nad rasami sosny zwyczajnej (Pinus silvestris) na ziemiach Polski. Biometrische Untersuchungen über die Rassen der gemeinen Kiefer (Pinus sylvestris) in Polen. Prace Rolniczo-Leśne PAU 5: 1-106. (in Polish, with German summary)

TOBOLSKI K. 1998. Stan poznania historii lasów, jezior i torfowisk Borów Tucholskich. The state of knowledge of the history of woodlands, lakes and peatlands of Bory Tucholskie. In: Park Narodowy Bory Tucholskie, J. Banaszak, K. Tobolski (eds.), Wydawnictwo Uczelniane Wyższej Szkoły Pedagogicznej w Bydgoszczy, 19-47. (in Polish, with English summary) 
URBANIAK L. 1998. Zróżnicowanie geograficzne sosny zwyczajnej (Pinus sylvestris L.) z terenu Eurazji na podstawie cech anatomicznych i morfologicznych igieł. Geographical differentiation of Scots pine (Pinus sylvestris L.) from the area of Eurasia on the basis of anatomical and morphological characters of needles. Adam Mickiewicz University Press, Poznań. Ser. Biol. nr 58, pp. 142. (in Polish, with English summary)

URBANIAK L., KARLIŃSKI L., KUBIS A., GRZEBYTA J. 2000. Zróżnicowanie sosny zwyczajnej (Pinus sylvestris L.) na terenie Wielkopolskiego Parku Narodowego. Differentiation of Scots pine (Pinus sylvestris L.) in the Wielkopolski National Park on the basis of needle morphological characters. Morena $\mathrm{Nr}$ 7, 41-52. (in Polish, with English summary)

VIDÂKIN A.N. 1981. Izmencivost' anatomo-morfologoceskogo stroeniâ chvoi v geograficeskich kul'turach Kirovskoj oblasti. Changeability of anatomo-morphological structure of Scotch pine needles in provenances of Kirov district. Lesoved. 5: 18-25. (in Russian, with English summary)
ZAJĄCZKOWSKI M. 1949. Studia na sosną zwyczajną w Tatrach i Pieninach. Studies on the common pine in the Tatra and Pieniny mountains (Western Carpatians). Prace Rolniczo-Leśne PAU 45. (in Polish, with English summary)

ŻELAWSKI W., GOWIN T. 1966. Variability of some needle characteristics in Scots pine (Pinus sylvestris L.) ecotypes grown on the comparative plantation. Ekol. Polska 14 A, 17: 275-283.

ŻELAWSKI W., GOWIN T. 1967. O rozmieszczeniu aparatów szparkowych na powierzchni igieł sosny pospolitej (Pinus sylvestris L.). Distribution of stomata on the surface of the needles

of Pinus sylvestris. Folia Forest. Pol., Ser. A, 13: 111-117. (in Polish, with English summary)

ŻELAWSKI W., NIWIŃSKI Z. 1966. Variability of some needle characteristics in Scots pine (Pinus sylvestris L.) ecotypes grown in native conditions. Ekol. Polska 14 A, 19: 301-308.

\section{ZMIENNOŚĆ MORFOLOGICZNA IGIEŁ POPULACJI SOSNY ZWYCZAJNEJ (PINUS SYLVESTRIS L.) W ODMIENNYCH ŚRODOWISKACH}

\section{STRESZCZENIE}

Zbadano fenotypową, morfologiczną zmienność pięciu cech igieł sosny zwyczajnej (Pinus sylvestris L.) w trzech populacjach. Dwie występują na terenie torfowisk, a jedna tworzy zniekształcony bór świeży wykazujący cechy boru suchego. Największą zmiennością charakteryzuje się cechy - a (długość igieł), b i d opisujące liczbę rzędów aparatów szparkowych występujących na wypukłej i płaskiej stronie igieł. Natomiast cechy stabilne, o małej zmienności międzyosobniczej, to - c i e, poprzez które opisano liczbę aparatów szparkowych występujących na $2 \mathrm{~mm}$ wypukłej i płaskiej stronie igieł. Wykazano odmienne korelacje cech w populacjach z torfowisk, w porównaniu z populacją występującą na terenie suchym. Na zróżnicowanie międzypopulacyjne, ujawnione na podstawie odmiennej ekspresji cech morfologicznych, mają znaczny wpływ, zarówno różne warunki edaficzne, jak i odrębna struktura genetyczna badanych populacji.

SŁOWA KLUCZOWE: Pinus sylvestris L., zmienność morfologiczna, igły, odmienne środowiska. 